\title{
$\angle S$ Research Suare \\ Impact of HCV viremia on HBV biomarkers in patients coinfected with HBV and HCV
}

\section{Chih-Wei Tseng}

Dalin Tzu Chi Hospital

Wen-Chun Liu

National Cheng Kung University Hospital

Chi-Yi Chen

Chiayi Christian Hospital: Ditmanson Medical Foundation Chia-Yi Christian Hospital

\section{Ting-Tsung Chang}

National Cheng Kung University Hospital

Kuo-Chih Tseng ( $\nabla$ tsengkuochih@gmail.com )

Dalin Tzu Chi Hospital https://orcid.org/0000-0002-4811-3018

\section{Research Article}

Keywords: hepatitis B surface antigen, hepatitis B core-related antigen, HBV pregenomic RNA, HBV/HCV coinfection

Posted Date: February 21st, 2022

DOI: https://doi.org/10.21203/rs.3.rs-1074002/v1

License: (c) (i) This work is licensed under a Creative Commons Attribution 4.0 International License. Read Full License

Version of Record: A version of this preprint was published at BMC Infectious Diseases on April 9th, 2022. See the published version at https://doi.org/10.1186/s12879-022-07326-1. 


\section{Abstract}

Backgrounds: Hepatitis B virus (HBV) biomarkers reflect the status of HBV infection; however, their role in patients with chronic hepatitis $B$ and $C(\mathrm{HBV} / \mathrm{HCV})$ coinfection remains unknown. This study evaluated the characteristics of HBV biomarkers in patients with chronic HBV/HCV coinfection.

Methods: One hundred untreated HBV/HCV coinfected patients were enrolled. Active viral infection was defined as viral load above 2,000 U/L and $15 \mathrm{U} / \mathrm{L}$ for HBV and HCV, respectively. Blood samples were analyzed for HBV biomarkers, including hepatitis B surface antigen (HBsAg), hepatitis B core-related antigen (HBcrAg), HBV DNA, and HBV pregenomic RNA (HBV pgRNA). The impact of HCV viremia was also studied.

Results: A total of 15 patients were HBV-inactive/HCV-inactive, 63 patients were HBV-inactive/HCV-active, 14 patients were $\mathrm{HBV}$-active/HCV-inactive and 8 patients were HBV-active/HCV-active. A total of 71 (71\%) patients were active HCV and $22(22 \%)$ were active HBV. HBsAg, HBcrAg, and HBV DNA correlated with each other $(P<0.001)$. HBV pgRNA displayed no correlations with HBV DNA, HBsAg, or HBcrAg. Patients with HCV viremia had significantly lower HBV DNA, HBsAg, and HBcrAg levels as well as higher HBV pgRNA levels and lower HBV DNA:pgRNA ratio than those without viremia (HBV DNA, $P<0.001 ; \mathrm{HBsAg}, P$ $=0.015 ; \mathrm{HBcrAg}, P=0.006$; HBV pgRNA, $P=0.073$; and HBV DNA:pgRNA ratio, $P<0.001)$.

Conclusions: In patients coinfected with HBV and HCV, HBsAg, HBcrAg, and HBV DNA significantly correlated with each other. HBV and HCV coinfected patients with HCV viremia have lower HBV DNA, HBsAg, HBcrAg, and HBV DNA:pgRNA ratio as well as higher HBV pgRNA levels.

\section{Background}

The prevalence of hepatitis B virus (HBV) and hepatitis C virus (HCV) coinfection is not uncommon in high epidemic areas because they share common routes of transmission [1, 2]. Patients with HBV/HCV coinfection have a higher risk of advanced liver disease, cirrhosis, and hepatocellular carcinoma (HCC) than those with monoinfection $[1,3]$. This population also carries the risk of HBV DNA reactivation following HCV direct-acting antiviral treatment.[4] Hence, understanding the viral interactions and molecular aspects of HBV/HCV coinfection are important for treatment.

Patients with HBV/HCV coinfection show a large spectrum of virological profiles, which demonstrates the complexity of the interaction between the two viruses. $[5,6]$ The most common clinical scenario among coinfected patients is HCV predominance with high HCV RNA levels and low HBV DNA levels; some patients experience HBV predominance with high HBV DNA levels and low HCV RNA levels, while others present alternating phases of dominance of one virus over the other [3].

Since the presence of HCV viremia may suppress HBV DNA, the status of HBV infection cannot be evaluated with HBV DNA simply due to the persistence of covalently closed circular DNA (cccDNA) in the nuclei of infected hepatocytes $[5,6]$. Although liver biopsy is the most accurate technique for 
quantification of intrahepatic cccDNA, its utility is limited by its invasive nature, the potential for sampling error, and the lack of a standardized assay [7, 8]. Several non-invasive biomarkers, including hepatitis B surface antigen (HBsAg), hepatitis B core-related antigen (HBcrAg), and HBV pregenomic RNA (HBV pgRNA), have been developed to reflect the activity of intrahepatic cccDNA [7, 9]. Growing evidence supports the serum HBV DNA correlated with serum HBsAg, HBcrAg, and HBV pgRNA in patients without antiviral treatment [9-11]. These biomarkers also serve as surrogate markers to reflect the cccDNA activity in virally suppressed patients with low detectable HBV DNA under nucleos(t)ide analogues (NA) therapy [12-15]. However, the above evidence does not disclose the characteristics of HBV biomarkers in $\mathrm{HBV} / \mathrm{HCV}$ coinfected patients.

The aim of this study was to investigate the presentation of and correlations among HBV biomarkers in patients with HBV/HCV coinfection. The impact of HCV viremia on HBV biomarkers was also evaluated.

\section{Methods}

\section{Subjects}

This study included 100 patients (> 20 years old) with chronic HBV/HCV coinfection who received regular follow-up at Dalin Tzu Chi Hospital and Chia-Yi Christian Hospital in Southern Taiwan from May 2017 to July 2019. The included patients were seropositive for HBsAg and the anti-HCV antibody (anti-HCV) for more than 6 months at the time of enrollment into the study. Patients aged $<20$ years or with any antiviral treatment history, human immunodeficiency virus or hepatitis delta virus infection, autoimmune hepatitis, primary biliary cirrhosis, sclerosing cholangitis, Wilson's disease, a1-antitrypsin deficiency, overt hepatic failure, or evidence of HCC were excluded.

Accordining to current guidelines, the cutoff vale using to define the $\mathrm{HBeAg}(-)$ patients with active $\mathrm{CHB}$ and those who required treatment was $2,000 \mathrm{IU} / \mathrm{mL}[16,17]$. Therefore, we used above $2,000 \mathrm{IU} / \mathrm{mL}$ as the definition of active HBV infection in this study. The HCV patients with detectable viremia required antiHCV treatment $[18,19]$. In this study, we used the COBAS $\circledast$ AmpliPrep/COBAS $\circledast$ TaqMan® HCV Test v2.0 (Roche Diagnostics, Rotkreuz, Switzerland) with a lower limit of quantification of $15 \mathrm{lU} / \mathrm{mL}$. Active HCV infection was defined as a virus load above $15 \mathrm{IU} / \mathrm{mL}$ [1]. According to these definitions, the cohort was divided into four different groups: $\mathrm{HBV}$-inactive/HCV-inactive group (BICI), HBV-inactive/HCV-active group (BICA), HBV-active/HCV-inactive group (BACl), and HBV-active/HCV-active group (BACA).

\section{Ethical considerations}

The study was approved by the Ethics Committee of Dalin Tzu Chi Hospital (approval number B10901004). Its design and conduct conformed to the ethical guidelines of the 1975 Declaration of Helsinki. Before commencement of the study, all patients signed informed consent forms.

\section{Clinical monitoring}


All subjects underwent examinations at the hospital's gastrointestinal outpatient department. Blood samples were collected at regular clinic visits. Blood samples were collected for evaluating levels of HBsAg, hepatitis B e antigen (HBeAg), HBcrAg, HBV pgRNA, HBV DNA, anti-HCV, HCV RNA, and HCV genotype. Serum aspartate aminotransferase (AST), alanine aminotransferase (ALT), total bilirubin, albumin, estimated glomerular filtration rate (eGFR), prothrombin time, and platelets were measured, and abdominal ultrasonography and alpha-fetoprotein (AFP) levels were evaluated. Fibrosis-4 (FIB-4) was used as a non-invasive test for liver fibrosis. [20] Liver cirrhosis was diagnosed by radiologic cirrhosis or FIB-4 > 3.25.[21] Radiologic cirrhosis was defined as coarse liver echotexture with nodularity and small liver size or the presence of features of portal hypertension (e.g., ascites, splenomegaly, and varices) noted on liver imaging.[22] A diagnosis of fatty liver was based on results from abdominal ultrasound, including features of hepatorenal echogenicity contrast, liver brightness, deep attenuation, and vessel blurring.[23] All ultrasonographic images were stored as photocopies.

\section{HBV/HCV quantification and HCV genotyping}

Serum HCV RNA levels were measured using the COBAS ${ }^{\circledR}$ AmpliPrep/COBAS ${ }^{\circledR}$ TaqMan ${ }^{\circledR}$ HCV Test v2.0 (Roche Diagnostics, Rotkreuz, Switzerland) with a lower limit of quantification of $15 \mathrm{IU} / \mathrm{mL}$. HCV genotyping was performed using the COBAS ${ }^{B}$ HCV GT assay (Roche Diagnostics). Serum HBV DNA levels were measured using the COBAS ${ }^{\circledR}$ HBV quantitative nucleic acid test on the COBAS $₫ 4800$ System (Roche Diagnostics), with a lower limit of quantification of $5 \mathrm{IU} / \mathrm{mL}$.

\section{HBsAg quantification}

HBsAg quantification was quantified using the two-step sandwich assay on a fully automated chemiluminescent enzyme immunoassay system (CLEIA) (Lumipulse G1200; Fujirebio, Inc., Tokyo, Japan) in a Lumipulse G1200 automated analyzer (Fujirebio, Inc.). The HBsAg-HQ reagents were provided by Fujirebio, Inc. The linear detection range of the HBsAg-HQ ranged from 5 to $150,000 \mathrm{mIU} / \mathrm{mL}$. If the serum exceeded the upper detection limit, it was diluted 200 -fold and remeasured.

\section{HBcrAg quantification}

This HBcrAg assay was performed using the Lumipulse G1200 CLEIA analyzer (Fujirebio, Inc.) with a lower limit of detection of $2.0 \log \mathrm{U} / \mathrm{mL}$ and a linear range of $3.0-7.0 \log \mathrm{U} / \mathrm{mL}(1 \mathrm{kU} / \mathrm{mL}$ is equal to $3 \log$ $\mathrm{U} / \mathrm{mL}$ ). Samples with HBcrAg level above $7 \log \mathrm{U} / \mathrm{mL}$ were diluted and retested to calculate the quantitative HBcrAg level. According to the Lumipulse ${ }^{\circledR}$ G HBcrAg Immunoreaction cartridges product inserts, the accuracy of the test was confirmed by assay values (calculated with the assay values in $\log \mathrm{U} / \mathrm{mL}$ ) for 3 in-house controls ranging within $\pm 5 \%$ of their control values.

\section{Extraction and reverse transcription of HBV pgRNA}

HBV RNA was extracted from $50 \mu$ l of serum using the Total RNA Extraction Miniprep System Kit according to the manufacturer's instructions (Viogene, Taipei, Taiwan) and treated with DNase I (Thermo Fisher Scientific, Waltham, MA, USA). Isolated HBV RNA was reverse transcribed using RevertAid reverse 
transcriptase (Thermo Fisher Scientific, Waltham, MA, USA) with an HBV specific RT primer for HBV pgRNA and total HBV RNA, respectively. Before commencing reverse transcription (RT), $20 \mu$ of RNA, $1 \mu \mathrm{l}$ of $10 \mu \mathrm{M}$ primer and $1 \mu \mathrm{l}$ of $10 \mathrm{mM}$ dNTPs (Thermo Fisher Scientific, Waltham, MA, USA) were mixed and incubated at $70^{\circ} \mathrm{C}$ for 5 mins and then placed immediately on ice for 1 min. RT was then initiated with the addition of RT reaction mix to a $35 \mu$ final volume at a final concentration 1x RT buffer, $1 \mu$ l of RNAse inhibitor (Life Technologies) and $1 \mu \mathrm{l}$ of RevertAid reverse transcriptase. Cycling conditions were $42^{\circ} \mathrm{C}$ for $60 \mathrm{~min}$, followed by $75^{\circ} \mathrm{C}$ for $5 \mathrm{~min}$. CDNA samples were held at $4^{\circ} \mathrm{C}$ before proceeding to quantitative real-time polymerase chain reaction (qPCR).

\section{Quantification of serum HBV pgRNA}

The levels of serum HBV RNA were detected by qPCR in LightCycler 480 II Real-time PCR Detection System (Roche, Mannheim, Germany) with a SYBR Green method. We modified a transcript- specific quantitative PCR (qPCR) assay previously described.[24] The primers used to detect HBV $3.5 \mathrm{~kb}$ RNA were showed in Supplementary Table 1. The standards were constructed by PCR using each primer from HBV full genome (accession number: KJ790199), and the PCR products were subsequently ligated into the $T \& A^{T M}$ Cloning Vector (Yeastern Biotech, Taiwan). The qPCR reaction mixture $(20 \mu \mathrm{l})$ contained $10 \mu \mathrm{l} 2 \mathrm{x}$ GoTaq ${ }^{\circledR}$ Green Master Mix (Promega Corp., Madison, WI), $0.5 \mu$ forward primer $(10 \mu \mathrm{M}), 0.5 \mu$ reverse primer $(10 \mu \mathrm{M}), 1 \mu \mathrm{l}$ cDNA template and $8 \mu \mathrm{l}$ double distilled water $(\mathrm{ddH} 2 \mathrm{O})$. The reaction mixture was denatured at $95^{\circ} \mathrm{C}$ for $5 \mathrm{~min}$, followed by 40 cycles at $95^{\circ} \mathrm{C}$ for $20 \mathrm{~s}, 60^{\circ} \mathrm{C}$ for $40 \mathrm{~s}$. The limit of detection (LOD) of serum HBV pgRNA was 1466 copies/mL, as calculated by probit analysis (Supplementary Table 2). For statistical analysis, those serum samples with HBV RNA below LOD or not detected were recorded as 1465 copies/mL (3.17 log copies/mL).

\section{Statistical analysis}

Statistical analysis was performed using SPSS Statistics version 19.0 software (SPSS Inc., Chicago, IL, USA). Variables were expressed as frequency count, percentage of total, and mean \pm standard deviation.

The chi-square test or Fisher's exact test was used for comparison of categorical data as appropriate. The Mann-Whitney $U$ test was used to compare differences in continuous variables between groups. In addition, linear regression analysis was performed to evaluate the correlations between HBV biomarkers. A positive $b$ coefficient indicated a positive association between HBV biomarkers. A $P$ value $<0.05$ was considered to be statistically significant.

\section{Results}

\section{Demographic and laboratory features of the study subjects}

A total of $100 \mathrm{HBV} / \mathrm{HCV}$ coinfected patients were enrolled in this study. There were 37 men and 63 women, and the mean patient age was 62.3 years (SD: 10.7 years) (Table 1). A total of 15 patients were $\mathrm{HBV}$-inactive/HCV-inactive, 63 patients were HBV-inactive/HCV-active, 14 patients were HBV-active/HCVinactive and 8 patients were HBV-active/HCV-active. A total of 71 (71\%) patients were active HCV and 22 
(22\%) were active HBV. All of the included patients were seronegative for HBeAg, except one patient with HBeAg-positive CHB in the BICA group. 
Table 1

Clinical and virological characteristics of the patients

\begin{tabular}{|c|c|c|c|c|c|c|}
\hline & $\begin{array}{l}\text { Total } \\
(n=100)\end{array}$ & $\begin{array}{l}\mathrm{BICl} \\
(n=15)\end{array}$ & $\begin{array}{l}\text { BICA } \\
(n=63)\end{array}$ & $\begin{array}{l}\text { BACl } \\
(n=14)\end{array}$ & $\begin{array}{l}\text { BACA } \\
(n=8)\end{array}$ & $\begin{array}{l}P \\
\text { value }\end{array}$ \\
\hline Age (years) $†$ & $\begin{array}{l}62.3 \pm \\
10.7\end{array}$ & $\begin{array}{l}58.8 \pm \\
12.4\end{array}$ & $63.6 \pm 10.7$ & $57.9 \pm 9.1$ & $65.5 \pm 6.4$ & 0.144 \\
\hline Male $(n, \%)$ & $\begin{array}{l}37 \\
(37.0 \%)\end{array}$ & $4(26.7 \%)$ & $24(38.1 \%)$ & $4(28.6 \%)$ & $5(62.5 \%)$ & 0.337 \\
\hline Cirrhosis (n, \%) & $\begin{array}{l}27 \\
(27.0 \%)\end{array}$ & $0(0.0 \%)$ & $21(33.3 \%)$ & $2(14.3 \%)$ & $4(50.0 \%)$ & 0.018 \\
\hline Fatty liver (n, \%) & $\begin{array}{l}35 \\
(35.0 \%)\end{array}$ & $5(33.3 \%)$ & 22 (34.9\%) & $7(50.0 \%)$ & $1(12.5 \%)$ & 0.364 \\
\hline Alcoholism & $\begin{array}{l}14 \\
(14.0 \%)\end{array}$ & $1(6.7 \%)$ & $9(14.3 \%)$ & $1(7.1 \%)$ & $3(37.5 \%)$ & 0.180 \\
\hline $\begin{array}{l}\text { HCV RNA } \\
(\log I U / m L) \dagger\end{array}$ & $4.5 \pm 2.3$ & $1.0 \pm 0.0$ & $5.9 \pm 0.9$ & $1.0 \pm 0.0$ & $5.8 \pm 0.5$ & $\begin{array}{l}<.001 \\
0.00\end{array}$ \\
\hline Genotype (n, \%) & & & & & & $\begin{array}{l}<.001 \\
0.00\end{array}$ \\
\hline Type 1 & $\begin{array}{l}45 \\
(45.0 \%)\end{array}$ & $0(0.0 \%)$ & 38 (60.3\%) & $0(0.0 \%)$ & $7(87.5 \%)$ & \\
\hline Type 2 & $\begin{array}{l}22 \\
(22.0 \%)\end{array}$ & $0(0.0 \%)$ & $21(33.3 \%)$ & $0(0.0 \%)$ & $1(12.5 \%)$ & \\
\hline Type 6 & $4(4.0 \%)$ & $0(0.0 \%)$ & $4(6.3 \%)$ & $0(0.0 \%)$ & $0(0.0 \%)$ & \\
\hline $\begin{array}{l}\text { HBV DNA } \\
(\log \mathrm{IU} / \mathrm{mL}) \dagger\end{array}$ & $2.3 \pm 1.5$ & $1.9 \pm 0.8$ & $1.5 \pm 0.7$ & $4.6 \pm 0.9$ & $4.8 \pm 1.5$ & $\begin{array}{l}<.001 \\
0.001\end{array}$ \\
\hline $\begin{array}{l}\text { HBsAg } \\
(\log I U / m L) \dagger\end{array}$ & $1.0 \pm 2.1$ & $1.4 \pm 1.9$ & $0.5 \pm 2.1$ & $1.9 \pm 1.8$ & $2.3 \pm 0.7$ & 0.004 \\
\hline $\begin{array}{l}\text { HBcrAg } \\
(\log I U / m L)+\end{array}$ & $3.2 \pm 0.6$ & $3.2 \pm 0.5$ & $3.1 \pm 0.5$ & $3.6 \pm 0.7$ & $3.5 \pm 1.2$ & 0.008 \\
\hline
\end{tabular}

$\mathrm{BICl}, \mathrm{HBV}$-inactive/HCV-inactive group; BICA, HBV-inactive/HCV-active group; BACl, HBV-active/HCVinactive group; $\mathrm{BACA}, \mathrm{HBV}$-active/HCV-active group (BACA); $\mathrm{HCV}$, hepatitis $\mathrm{C}$ virus; $\mathrm{HBV}$, hepatitis $\mathrm{B}$ virus; $\mathrm{HBsAg}$, hepatitis B surface antigen; $\mathrm{HBcrAg}$, hepatitis B core-related antigen; pgRNA, pregenomic RNA; FIB-4, fibrosis-4 index; ALT, alanine aminotransferase; AST, aspartate aminotransferase; AFP, alpha-fetoprotein; eGFR, estimated glomerular filtration rate.

†Data are expressed as mean \pm standard deviation. 


\begin{tabular}{|c|c|c|c|c|c|c|}
\hline & $\begin{array}{l}\text { Total } \\
(n=100)\end{array}$ & $\begin{array}{l}\text { BICl } \\
(n=15)\end{array}$ & $\begin{array}{l}\text { BICA } \\
(n=63)\end{array}$ & $\begin{array}{l}\text { BACl } \\
(n=14)\end{array}$ & $\begin{array}{l}\text { BACA } \\
(n=8)\end{array}$ & $\begin{array}{l}P \\
\text { value }\end{array}$ \\
\hline $\begin{array}{l}\text { HBV pgRNA } \\
\text { (copies/mL) † }\end{array}$ & $4.1 \pm 1.2$ & $3.7 \pm 1.2$ & $4.2 \pm 1.2$ & $3.9 \pm 1.1$ & $4.9 \pm 1.6$ & 0.119 \\
\hline FIB-4† & $2.5 \pm 2.1$ & $1.4 \pm 0.5$ & $2.7 \pm 2.4$ & $2.1 \pm 1.8$ & $3.5 \pm 1.7$ & 0.008 \\
\hline $\begin{array}{l}\text { Total bilirubin (mg/dL) } \\
+\end{array}$ & $0.7 \pm 0.3$ & $0.7 \pm 0.3$ & $0.7 \pm 0.4$ & $0.9 \pm 0.3$ & $0.7 \pm 0.3$ & 0.166 \\
\hline $\operatorname{ALT}(\mathrm{U} / \mathrm{L}) \dagger$ & $\begin{array}{l}65.2 \pm \\
55.0\end{array}$ & $\begin{array}{l}35.7 \pm \\
25.2\end{array}$ & $73.6 \pm 55.2$ & $29.8 \pm 9.5$ & $\begin{array}{l}106.4 \pm \\
79.5\end{array}$ & $<001$ \\
\hline AST $(U / L) \dagger$ & $\begin{array}{l}48.4 \pm \\
40.5\end{array}$ & $\begin{array}{l}28.3 \pm \\
18.1\end{array}$ & $52.6 \pm 36.6$ & $26.9 \pm 9.3$ & $\begin{array}{l}91.2 \pm \\
80.2\end{array}$ & $<.001$ \\
\hline Albumin $(\mathrm{g} / \mathrm{dL}) \dagger$ & $4.3 \pm 0.3$ & $4.5 \pm 0.2$ & $4.3 \pm 0.4$ & $4.3 \pm 0.2$ & $4.2 \pm 0.2$ & 0.123 \\
\hline $\begin{array}{l}\text { Prothrombin time } \\
(\mathrm{sec}) \dagger\end{array}$ & $10.8 \pm 0.7$ & $10.7 \pm 0.3$ & $10.7 \pm 0.8$ & $11.1 \pm 0.6$ & $10.7 \pm 0.7$ & 0.172 \\
\hline $\operatorname{AFP}(U / L) \dagger$ & $\begin{array}{l}28.3 \pm \\
192.8\end{array}$ & $3.2 \pm 2.4$ & $\begin{array}{l}40.7 \pm \\
241.4\end{array}$ & $3.9 \pm 4.4$ & $\begin{array}{l}16.0 \pm \\
24.7\end{array}$ & 0.035 \\
\hline $\begin{array}{l}\text { Platelets } \\
\left(\times 10^{3} / \mathrm{mm}^{3}\right)+\end{array}$ & $\begin{array}{l}186.2 \pm \\
58.2\end{array}$ & $\begin{array}{l}205.5 \pm \\
45.6\end{array}$ & $\begin{array}{l}183.0 \pm \\
59.99\end{array}$ & $\begin{array}{l}192.4 \pm \\
58.4\end{array}$ & $\begin{array}{l}163.9 \pm \\
62.1\end{array}$ & 0.432 \\
\hline eGFR† & $\begin{array}{l}86.6 \pm \\
24.7\end{array}$ & $\begin{array}{l}82.5 \pm \\
16.3\end{array}$ & $85.0 \pm 25.5$ & $\begin{array}{l}100.7 \pm \\
26.7\end{array}$ & $\begin{array}{l}86.6 \pm \\
24.7\end{array}$ & 0.194 \\
\hline \multicolumn{7}{|c|}{$\begin{array}{l}\text { BICI, HBV-inactive/HCV-inactive group; BICA, HBV-inactive/HCV-active group; BACI, HBV-active/HCV- } \\
\text { inactive group; BACA, HBV-active/HCV-active group (BACA); HCV, hepatitis C virus; HBV, hepatitis B } \\
\text { virus; HBsAg, hepatitis B surface antigen; HBcrAg, hepatitis B core-related antigen; pgRNA, pregenomic } \\
\text { RNA; FIB-4, fibrosis-4 index; ALT, alanine aminotransferase; AST, aspartate aminotransferase; AFP, } \\
\text { alpha-fetoprotein; eGFR, estimated glomerular filtration rate. }\end{array}$} \\
\hline
\end{tabular}

Based on viral load, patients were placed into one of the following groups: $\mathrm{BICl}(\mathrm{n}=15 ; 15.0 \%), \mathrm{BICA}(\mathrm{n}=$ $63 ; 63.0 \%), \mathrm{BACl}(n=14 ; 14.0 \%)$, or BACA $(n=8 ; 8.0 \%)$. The demographic, clinical, and virological characteristics of each group are presented in Table 1. HBV DNA, HBsAg, HBcrAg, and HCV RNA showed statistically significant differences among the four groups while HBV pgRNA did not. Liver enzyme (ALT/AST), cirrhosis, FIB-4, and AFP levels in the BICA and BACA groups were higher than those in the $\mathrm{BICl}$ and $\mathrm{BACl}$ groups. There were no statistically significant differences among the four groups regarding age, sex, fatty liver, alcoholism, albumin, total bilirubin, eGFR, prothrombin time, and platelet count.

\section{Hbv Biomarkers Of The Patients With Hbv/hcv Coinfection}


Figure 1 shows the HBV biomarkers (including HBV DNA, HBsAg, HBcrAg, and HBV pgRNA) of each of the four groups. The HBV-active groups (BACA \& BACl) had significantly higher level of HBV DNA (Fig. 1A; BACA vs. BICA, $P<0.001$; BACA vs. $\mathrm{BICl}, P<0.001$; $\mathrm{BACl}$ vs. $\mathrm{BICA}, P<0.001 ; \mathrm{BACl}$ vs. $\mathrm{BICl}, P<0.001)$. Levels of serum HBsAg in the HBV-active groups (BACA \& BACl) were significantly higher than that in the BICA group (Fig. 1B; BACA vs. BICA, $P=0.013 ; B A C I$ vs. $B I C A, P=0.007$ ). The serum HBcrAg level in the $\mathrm{BACl}$ group was higher than that in the BICA group (Fig. 1C; $P=0.001$ ). In addition, the level of HBV pgRNA in the BACA group was significantly higher than that in the BICl group (Fig. 1D; $P=0.001$ ); however, there was no significant difference in the HBV pgRNA level among the four groups (Table $1 ; P=$ 0.119). Interestingly, using HBV DNA divided by HBV pgRNA, the HBV DNA:HBV pgRNA ratio was significantly higher in BACA and $\mathrm{BACl}$ than in $\mathrm{BICl}$ and BICA (Fig. 1E; BACA vs. BICA, $P<0.001$; BACA vs. $\mathrm{BICl}, P=0.023 ; \mathrm{BACl}$ vs. BICA, $P<0.001 ; \mathrm{BACl}$ vs. $\mathrm{BICl}, P<0.001)$.

\section{Correlations between HBV biomarkers of the patients with HBV/HCV coinfection}

Linear regression analyses demonstrated positive linear correlations between $\mathrm{HBsAg}, \mathrm{HBcrAg}$, and $\mathrm{HBV}$ DNA. HBV DNA significantly correlated with HBsAg (Fig. 2A; $R=0.476, R^{2}=0.227, \beta=0.463$, and $P<$ 0.001 ) and $\mathrm{HBcrAg}$ (Fig. $2 B ; \mathrm{R}=0.474, \mathrm{R}^{2}=0.225, \beta=0.474$, and $P<0.001$ ). HBsAg also showed a positive correlation with HBcrAg (Fig. $2 \mathrm{C} ; \mathrm{R}=0.392, \mathrm{R}^{2}=0.153, \beta=0.392$, and $P<0.001$ ). However, HBV pgRNA showed no correlations with HBV DNA, HBsAg, and HBcrAg (Fig. 2D-F; HBV DNA, R=0.017, $\mathrm{R}^{2}=$ $0.0003, \beta=-0.017$, and $P=0.864 ; \mathrm{HBsAg}, \mathrm{R}=0.111, \mathrm{R}^{2}=0.012, \beta=0.111$, and $P=0.270$; and $\mathrm{HBcrAg}, \mathrm{R}=$ $0.086, \mathrm{R}^{2}=0.0037, \beta=-0.086$, and $P=0.395$, respectively).

\section{HBV biomarkers in HBV/HCV coinfected patients with and without HCV viremia}

In $\mathrm{HBV} / \mathrm{HCV}$ coinfected patients with $\mathrm{HCV}$ viremia, HBV DNA, HBsAg, and HBcrAg were significantly reduced than in those without viremia (Fig. 3A-C; HBV DNA, $P<0.001$; HBsAg, $P=0.015$; and HBcrAg, $P=$ 0.006 , respectively). Although the difference was not statistically significant, patients with viremia exhibited higher HBV pgRNA levels than those without viremia (Fig. 3D; $P=0.073$ ). Interestingly, patients with viremia had a lower HBV DNA:HBV pgRNA ratio than those without viremia, indicating lower reverse transcription efficiency of pgRNA in patients with viremia (Fig. 3E; $P<0.001$ ). The amount of HCV RNA had a negative correlation between HCV RNA and HBV DNA/ pgRNA ratio (Fig. $3 F ; R=0.416, R^{2}=0.173, \beta$ $=-0.416$, and $P<0.001)$.

\section{Discussion}

The present study demonstrated that HBV DNA, HBsAg, and HBcrAg show linear positive correlations with each other in HBV/HCV coinfected patients. However, HBV pgRNA levels were not associated with HBV DNA, HBsAg, or HBcrAg. The presence of HCV viremia appeared to suppress HBV DNA, HBsAg, HBcrAg, and indicated an increasing level of HBV pgRNA. The lower HBV DNA:HBV pgRNA ratio in patients with HCV viremia indicated ineffective reverse transcription of HBV pgRNA. 
In line with previous epidemiology reports, the current study determined that active HCV infection plays a dominant role in patients with HBV/HCV coinfection (Table 1).[2, 25] Active HCV status in patients with HBV/ HCV coinfection correlated with higher extent of liver injury (ALT/AST), higher fibrosis scores (FIB4), and enhanced cirrhosis (Table 1). However, the association between high HBV DNA (active HBV) and patient characteristics (such as liver injury or cirrhosis) was not significant. This observation suggests that identification of non-invasive biomarkers, other than HBV DNA, is necessary to reflect the transcriptional activity of intrahepatic viruses and immune response.

Several reports have demonstrated that serum HBV DNA correlates with serum HBsAg, HBcrAg, and HBV pgRNA during the natural course of hepatitis B viral infection.[26-29] One recent meta-analysis including 5,591 patients without antiviral therapy found a close correlation between HBcrAg and HBV DNA.[10] The optimal cut-offs ( $\log \mathrm{U} / \mathrm{mL}$ ) were 3.6 and 4.5 to diagnose HBV DNA levels $(\mathrm{IU} / \mathrm{mL})$ of $\geq 2,000$ and $\geq$ 20,000 , respectively.[10] The levels of serum HBV pgRNA strongly correlate with serum HBV DNA in treatment-naïve patients, but the correlation becomes weaker upon receiving NAs.[30] As for presentation in patients with HBV monoinfection, our study showed that HBsAg and HBcrAg levels changed in parallel with the HBV DNA level in the HBV/HCV coinfected patients (Fig. 2). Positive linear correlations between HBsAg, HBcrAg, and HBV DNA were identified (Fig. 2). In contrast, lack of an association between serum HBV pgRNA and other HBV biomarkers was noted in our study (Fig. 2D-F). Theoretically, both serum HBV DNA and HBV pgRNA can be useful markers for assessing HBV cccDNA activity in treatment-naïve patients. However, HBV DNA is suppressed due to halted HBV pgRNA reverse transcription by HCV viremia [31, 32], making HBV pgRNA a more direct marker for cccDNA. Thus, serum HBV pgRNA may be a surrogate marker for intrahepatic HBV cccDNA in patients with HBV/HCV coinfection compared to serum HBV DNA, HBsAg, and HBcrAg. However, further studies are warranted to clarify this observation.

The persistence of serum HBV pgRNA levels raises interest in the role of HCV viremia in HBV/HCV coinfected patients. In general, HCV is the dominant virus that actively replicates and suppresses the replication of HBV. $[5,33]$ The mechanism of this interaction is not well-understood, although several hypotheses regarding direct or indirect (mediated by various host immune responses) viral interference have been proposed to explain the dominant role of HCV. A number of studies have suggested that HBV suppression is mediated by the HCV core protein [31,32] In coinfection, the HCV core protein was found to form a complex with HBV polymerase and impede its function.[31, 32] Another hypothesis states that $\mathrm{HCV}$ infection activates interferon production within the hepatocytes, thereby suppressing HBV further due to its antiviral effects. $[3,5]$ Our study revealed that HCV viremia is associated with low HBV DNA, $\mathrm{HBsAg}$, and HBcrAg. These results suggest that HCV may suppress HBV polymerase and impair mRNA translation, which reduces the production of HBV DNA, HBsAg, and HBcrAg in patients with $\mathrm{HBV} / \mathrm{HCV}$ coinfection.

In contrast with the suppression of HBV DNA, HBsAg, and HBcrAg, our study also discovered a trend of higher HBV pgRNA associated with HCV viremia (including in the BACA and BICA groups) (Fig. 3D; $P=$ 0.073). In HBV replication cycle, circular DNA genome of mature HBV from the linear pgRNA template takes place inside the core. [34] After HBV polymerase protein binding to the epsilon $(\varepsilon)$ loop at the $5^{\prime}$ end 
of pgRNA, assembly of HBV begins with packaging of pgRNA into immature nucleocapsids (NC), which are converted to mature NCs containing the genomic relaxed circular (RC) DNA as a result of reverse transcription. [35] However, a number of studies have investigated that HCV core protein could complex with HBV polymerase and impede its function. [5], [31], [36] Therefore, HBV pgRNA virion levels increased in BACA and BICA groups might result from blocking the reverse transcription activity of HBV DNA polymerase while HCV core protein capture HBV polymerase. In general, the levels of serum HBV pgRNA strongly correlate with serum HBV DNA in treatment-naïve patients.[30] The lower level of HBV pgRNA is reasonable in the $\mathrm{BICl}$ and $\mathrm{BICA}$ groups due to the low HBV replication activity.[37] However, HCV viremia increased the level of HBV pgRNA in the BICA group and caused the BICA group to have comparable HBV pgRNA levels to the BACA and BACl groups (Fig. 1D). Combined with the effects of HBV viremia and HCV viremia, the BACA group with both viremia effects had higher HBV pgRNA levels than the BICl group with both negative viremia effects (Fig. 1D; $P<0.001$ ). Further studies are necessary to address the correlation between HCV viremia and HBV pgRNA.

Combined serum HBV DNA and HBV pgRNA levels are better indicators of cccDNA activity and the HBV DNA:HBV pgRNA ratio reflects the HBV polymerase protein reverse transcription activity.[38] The current study demonstrated that HCV viremia leads to a lower HBV DNA:HBV pgRNA ratio that is compatible with the suppression of HBV polymerase by HCV.[31, 32] Several studies have reported that NAs or pegylated interferon alpha therapy can effectively block reverse transcription and suppress HBV viral replication, causing an inversion of the HBV DNA:HBV RNA ratio.[39, 40] As the presentation of anti-HBV therapy, the current study demonstrated that patients with HCV viremia present a lower HBV DNA level and show a higher serum HBV pgRNA level than those without viremia. Lower HBV DNA:HBV pgRNA ratio further indicated lower reverse transcription efficiency of pgRNA in patients with HCV viremia.

There were several limitations in this study. First, the case number of some groups was small due to the nature of virological profiles. Most patients were HCV-dominant. However, this study remains the largest cohort study on this subject. This report adds new information about the characteristics of HBV biomarkers in patients with HBV/HCV coinfection. Second, our results do not provide information regarding the molecular mechanism of the increase in HBV pgRNA levels in patients with HCV viremia. Further studies are needed to clarify these aspects. Third, we compared the dynamic change of most HBV biomarkers, including HBsAg, HBV DNA, HBcrAg and HBV pgRNA in the current study. However, the analysis of other circulating HBV biomarkers such as microRNA or HBV nucleic acid-related antigen were not done. Further study maybe required.

Despite these limitations, this study has several strengths. Although there are many studies about the HBV biomarkers in HBV patients, this is the first study with the comprehensive investigation of various HBV biomarkers in HBV/HCV coinfected patients. Second, it is interesting to note that HBV pgRNA levels increase, especially when HCV proliferation is active. This is not mentioned in previous reports. Third, the relatively high HBV pgRNA level, low HBV DNA and low HBV DNA:HBV pgRNA ratio suggested that HCV viremia may be responsible for the decrease of HBV pgRNA RT activity. The results suggested that those 
HBV biomarkers have the potential as the predictive biomarkers of HBV reactivation following HCV directacting antiviral treatment in patients with $\mathrm{HBV} / \mathrm{HCV}$ coinfection.

\section{Conclusions}

The current study revealed that HBV DNA, HBsAg, and HBcrAg significantly correlated with each other in patients coinfected with HBV and HCV. In addition, HBV and HCV coinfected patients with HCV viremia have lower HBV DNA, HBsAg, HBcrAg, and HBV DNA:pgRNA ratio as well as higher HBV pgRNA than those without viremia. The possible involvement of HCV RNA in HBV mRNA translation and pgRNA reverse transcription activity needs further investigation.

\section{Abbreviations}

hepatitis B virus (HBV); hepatitis C virus (HCV); hepatocellular carcinoma (HCC); covalently closed circular DNA (cccDNA); hepatitis B surface antigen ( $\mathrm{HBsAg})$; hepatitis B core-related antigen (HBcrAg); HBV pregenomic RNA (HBV pgRNA); nucleos(t)ide analogues (NA); anti-hepatitis $\mathrm{C}$ antibody (anti-HCV); hepatitis B e antigen (HBeAg); aspartate aminotransferase (AST); alanine aminotransferase (ALT); estimated glomerular filtration rate (eGFR); alpha-fetoprotein (AFP); fibrosis-4 (FIB-4); nucleocapsids (NC)

\section{Declarations}

\section{Ethics approval and consent to participate}

The study was approved by the Ethics Committee of Dalin Tzu Chi Hospital (approval number B10901004). Its design and conduct conformed to the ethical guidelines of the 1975 Declaration of Helsinki. Before commencement of the study, all patients signed informed consent forms.

\section{Consent for publication}

Not applicable.

\section{Availability of data and material}

The datasets used in the current study are available from the corresponding author on reasonable request.

\section{Competing interests}

The authors declare that they have no competing interests.

\section{Funding}


This study was funded by the Dalin Tzu Chi Hospital, Buddhist Tzu Chi Medical Foundation through grant number DTCRD 109-1-08 and the Buddhist Tzui Chi Medical Foundation through grand number TCMF-MP 109-01-01. The sponsor played no role in the study design; in collection, analysis, and interpretation of data; in the writing of the report; or in the decision to submit the article for publication.

\section{Authors' contributions}

Study concept and design: K.C.T; Data acquisition: C.W.T, C.Y.C., K.C.T., Data analysis and interpretation: C.W.T, W.C.L., T.T.C., K.C.T., Drafting of the manuscript; critical revision of the manuscript for important intellectual content: C.W.T., T.T.C., K.C.T., Statistical analysis: C.W.T., Obtained funding: K.C.T. Administrative, technical, or material support; study supervision: K.C.T

\section{Acknowledgements}

We would like to thank Miss Yi-Ting He for her assistance in procuring the medical records of the study participants.

\section{References}

1. Liu CJ, Chen PJ, Chen DS, Tseng TC, Kao JH. Perspectives on dual hepatitis B and C infection in Taiwan. J Formos Med Association = Taiwan yi zhi. 2016;115(5):298-305.

2. Dai CY, Yu ML, Chuang WL, Lin ZY, Chen SC, Hsieh MY, Wang LY, Tsai JF, Chang WY. Influence of hepatitis $C$ virus on the profiles of patients with chronic hepatitis B virus infection. J Gastroenterol Hepatol. 2001;16(6):636-40.

3. Konstantinou D, Deutsch M. The spectrum of HBV/HCV coinfection: epidemiology, clinical characteristics, viralinteractions and management. Ann Gastroenterol. 2015;28(2):221-8.

4. Liu CJ, Kao JH. Hepatitis C and hepatitis B coinfection. Clinical Dilemmas in Viral Liver Disease 2020:182-188.

5. Mavilia MG, Wu GY. HBV-HCV Coinfection: Viral Interactions, Management, and Viral Reactivation. J Clin translational Hepatol. 2018;6(3):296-305.

6. Jung MK, Shin EC. Regulatory T Cells in Hepatitis B and C Virus Infections. Immune Netw. 2016;16(6):330-6.

7. Mak LY, Wong DK, Cheung KS, Seto WK, Lai CL, Yuen MF. Review article: hepatitis B core-related antigen ( $\mathrm{HBcrAg})$ : an emerging marker for chronic hepatitis $B$ virus infection. Aliment Pharmacol Ther. 2018;47(1):43-54.

8. Gill US, Pallett LJ, Kennedy PTF, Maini MK. Liver sampling: a vital window into HBV pathogenesis on the path to functional cure. Gut. 2018;67(4):767-75.

9. Ou Q, Guo J, Zeng Y, Chen $\mathrm{H}$. Insights for clinical diagnostic indicators of virus and host in chronic hepatitis B infection. J Viral Hepatitis. 2020;27(3):224-32. 
10. Yoshida K, Desbiolles A, Feldman SF, Ahn SH, Alidjinou EK, Atsukawa M, Bocket L, Brunetto MR, Buti M, Carey I, et al: Assay for Hepatitis B Core-related Antigen Identify Patients With High Viral Load: Systematic Review and Meta-analysis of Individual Participant Data. Clinical gastroenterology and hepatology: the official clinical practice journal of the American Gastroenterological Association 2020.

11. Liu S, Zhou B, Valdes JD, Sun J, Guo H. Serum Hepatitis B Virus RNA: A New Potential Biomarker for Chronic Hepatitis B Virus Infection. Hepatology. 2019;69(4):1816-27.

12. Wang L, Cao X, Wang Z, Gao Y, Deng J, Liu X, Zhuang H. Correlation of HBcrAg with Intrahepatic Hepatitis B Virus Total DNA and Covalently Closed Circular DNA in HBeAg-Positive Chronic Hepatitis B Patients. Journal of clinical microbiology 2019, 57(1).

13. Chen EQ, Wang ML, Tao YC, Wu DB, Liao J, He M, Tang H. Serum HBcrAg is better than HBV RNA and HBsAg in reflecting intrahepatic covalently closed circular DNA. J Viral Hepatitis. 2019;26(5):586-95.

14. Suzuki F, Miyakoshi H, Kobayashi M, Kumada H. Correlation between serum hepatitis B virus corerelated antigen and intrahepatic covalently closed circular DNA in chronic hepatitis B patients. J Med Virol. 2009;81(1):27-33.

15. Cornberg M, Wong VW, Locarnini S, Brunetto M, Janssen HLA, Chan HL. The role of quantitative hepatitis B surface antigen revisited. J Hepatol. 2017;66(2):398-411.

16. EASL. 2017 Clinical Practice Guidelines on the management of hepatitis B virus infection. Journal of hepatology 2017, 67(2):370-398.

17. Terrault NA, Lok ASF, McMahon BJ, Chang KM, Hwang JP, Jonas MM, Brown RS Jr, Bzowej NH, Wong JB. Update on prevention, diagnosis, and treatment of chronic hepatitis B: AASLD 2018 hepatitis B guidance. Hepatology. 2018;67(4):1560-99.

18. Hepatitis CG. 2018 Update: AASLD-IDSA Recommendations for Testing, Managing, and Treating Hepatitis C Virus Infection. Clin Infect diseases: official publication Infect Dis Soc Am. 2018;67(10):1477-92.

19. EASL recommendations on treatment of hepatitis C: Final update of the series( $(\mathbb{\nabla})$. Journal of hepatology 2020, 73(5):1170-1218.

20. Vergniol J, Boursier J, Coutzac C, Bertrais S, Foucher J, Angel C, Chermak F, Hubert IF, Merrouche W, Oberti $\mathrm{F}$, et al. Evolution of noninvasive tests of liver fibrosis is associated with prognosis in patients with chronic hepatitis C. Hepatology. 2014;60(1):65-76.

21. European Association for the Study of the Liver. Electronic address eee, European Association for the Study of the L: EASL Recommendations on Treatment of Hepatitis C 2018. J Hepatol. 2018;69(2):461-511.

22. Huang JF, Yu ML, Lee CM, Dai CY, Hou NJ, Hsieh MY, Wang JH, Lu SN, Sheen IS, Lin SM, et al. Sustained virological response to interferon reduces cirrhosis in chronic hepatitis C: a 1,386-patient study from Taiwan. Aliment Pharmacol Ther. 2007;25(9):1029-37.

23. Hamaguchi M, Kojima T, Itoh Y, Harano Y, Fujii K, Nakajima T, Kato T, Takeda N, Okuda J, Ida K, et al. The severity of ultrasonographic findings in nonalcoholic fatty liver disease reflects the metabolic 
syndrome and visceral fat accumulation. Am J Gastroenterol. 2007;102(12):2708-15.

24. Wang J, Shen T, Huang X, Kumar GR, Chen X, Zeng Z, Zhang R, Chen R, Li T, Zhang T, et al. Serum hepatitis $B$ virus RNA is encapsidated pregenome RNA that may be associated with persistence of viral infection and rebound. J Hepatol. 2016;65(4):700-10.

25. Yan LB, Rao HY, Ma YJ, Bai L, Chen EQ, Du LY, Yang RF, Wei L, Tang H, Group CCS. Hepatitis B virus infection in Chinese patients with hepatitis $C$ virus infection: prevalence, clinical characteristics, viral interactions and host genotypes: a nationwide cross-sectional study. BMJ open. 2016;6(10):e012016.

26. Seto WK, Wong DK, Fung J, Huang FY, Liu KS, Lai CL, Yuen MF. Linearized hepatitis B surface antigen and hepatitis B core-related antigen in the natural history of chronic hepatitis B. Clin Microbiol infection: official publication Eur Soc Clin Microbiol Infect Dis. 2014;20(11):1173-80.

27. Maasoumy B, Wiegand SB, Jaroszewicz J, Bremer B, Lehmann P, Deterding K, Taranta A, Manns MP, Wedemeyer H, Glebe D, et al: Hepatitis B core-related antigen (HBcrAg) levels in the natural history of hepatitis B virus infection in a large European cohort predominantly infected with genotypes A and D. Clinical microbiology and infection: the official publication of the European Society of Clinical Microbiology and Infectious Diseases 2015, 21(6):606 e601-610.

28. Jaroszewicz J, Calle Serrano B, Wursthorn K, Deterding K, Schlue J, Raupach R, Flisiak R, Bock CT, Manns MP, Wedemeyer $\mathrm{H}$, et al. Hepatitis B surface antigen (HBsAg) levels in the natural history of hepatitis B virus (HBV)-infection: a European perspective. J Hepatol. 2010;52(4):514-22.

29. van Campenhout MJH, van Bommel F, Pfefferkorn M, Fischer J, Deichsel D, Boonstra A, van Vuuren AJ, Berg T, Hansen BE, Janssen HLA. Host and viral factors associated with serum hepatitis $B$ virus RNA levels among patients in need for treatment. Hepatology. 2018;68(3):839-47.

30. van Bommel F, Bartens A, Mysickova A, Hofmann J, Kruger DH, Berg T, Edelmann A. Serum hepatitis $B$ virus RNA levels as an early predictor of hepatitis $B$ envelope antigen seroconversion during treatment with polymerase inhibitors. Hepatology. 2015;61(1):66-76.

31. Chen SY, Kao CF, Chen CM, Shih CM, Hsu MJ, Chao CH, Wang SH, You LR, Lee YH. Mechanisms for inhibition of hepatitis $B$ virus gene expression and replication by hepatitis $C$ virus core protein. J Biol Chem. 2003;278(1):591-607.

32. Shih CM, Chen CM, Chen SY, Lee YH. Modulation of the trans-suppression activity of hepatitis $\mathrm{C}$ virus core protein by phosphorylation. J Virol. 1995;69(2):1160-71.

33. Mak LY, Seto WK, Fung J, Yuen MF. New Biomarkers of Chronic Hepatitis B. Gut Liver. 2019;13(6):589-95.

34. Wang JC, Nickens DG, Lentz TB, Loeb DD, Zlotnick A. Encapsidated hepatitis B virus reverse transcriptase is poised on an ordered RNA lattice. Proc Natl Acad Sci U S A. 2014;111(31):11329-34.

35. Cui X, Luckenbaugh L, Bruss V, Hu J. Alteration of Mature Nucleocapsid and Enhancement of Covalently Closed Circular DNA Formation by Hepatitis B Virus Core Mutants Defective in CompleteVirion Formation. J Virol. 2015;89(19):10064-72. 
36. Gordon SC, Sherman KE. Treatment of HBV/HCV coinfection: releasing the enemy within. Gastroenterology. 2009;136(2):393-6.

37. Prakash K, Rydell GE, Larsson SB, Andersson M, Norkrans G, Norder H, Lindh M. High serum levels of pregenomic RNA reflect frequently failing reverse transcription in hepatitis $B$ virus particles. Virol $\mathrm{J}$. 2018;15(1):86.

38. Huang H, Wang J, Li W, Chen R, Chen X, Zhang F, Xu D, Lu F. Serum HBV DNA plus RNA shows superiority in reflecting the activity of intrahepatic cccDNA in treatment-naive HBV-infected individuals. J Clin virology: official publication Pan Am Soc Clin Virol. 2018;99-100:71-8.

39. Huang YW, Takahashi S, Tsuge M, Chen CL, Wang TC, Abe H, Hu JT, Chen DS, Yang SS, Chayama K, et al. On-treatment low serum HBV RNA level predicts initial virological response in chronic hepatitis B patients receiving nucleoside analogue therapy. Antivir Ther. 2015;20(4):369-75.

40. Huang YW, Chayama K, Tsuge M, Takahashi S, Hatakeyama T, Abe H, Hu JT, Liu CJ, Lai MY, Chen DS, et al. Differential effects of interferon and lamivudine on serum HBV RNA inhibition in patients with chronic hepatitis B. Antivir Ther. 2010;15(2):177-84.

\section{Figures}

Figure 1

Expression of HBV DNA, HBsAg, HBcrAg, and HBV pgRNA in in patients coinfected with $\mathrm{HBV} / \mathrm{HCV}(\mathrm{n}=$ 100). A. HBV DNA was significantly higher in the HBV-active groups (Fig. 1A; BACA vs. BICA, $P<0.001$; BACA vs. $\mathrm{BICl}, P<0.001$; $\mathrm{BACl}$ vs. $\mathrm{BICA}, P<0.001$; and $\mathrm{BACl}$ vs. $\mathrm{BICl}, P<0.001)$. B. Serum HBsAg in the HBV-active groups was significantly higher than that in the BICA group (Fig. 1B; BACA vs. BICA, $P=0.013$; and $\mathrm{BACl}$ vs. $\mathrm{BICA}, P=0.007)$. C. Serum HBcrAg in the BACl group was higher than that in BICA group (Fig. 1C; $P=0.001$ ). D. HBV pgRNA in the BACA group was significantly higher than that in the $\mathrm{BICl}$ group (Fig. 1D; $P<0.001$ ). E. The HBV DNA:HBV pgRNA ratio was significantly higher in the BACA and BACl groups than in the $\mathrm{BICl}$ and $\mathrm{BICA}$ groups (Fig. 1E; BACA vs. $\mathrm{BICA}, P<0.001 ; \mathrm{BACA}$ vs. $\mathrm{BICl}, P=0.023 ; \mathrm{BACl}$ vs. BICA, $P<0.001$; and $\mathrm{BACl}$ vs. $\mathrm{BICl}, P<0.001)$.

HBV, hepatitis B virus; HCV, hepatitis C virus; HBsAg, hepatitis B surface antigen; HBcrAg, hepatitis B corerelated antigen; pgRNA, pregenomic RNA

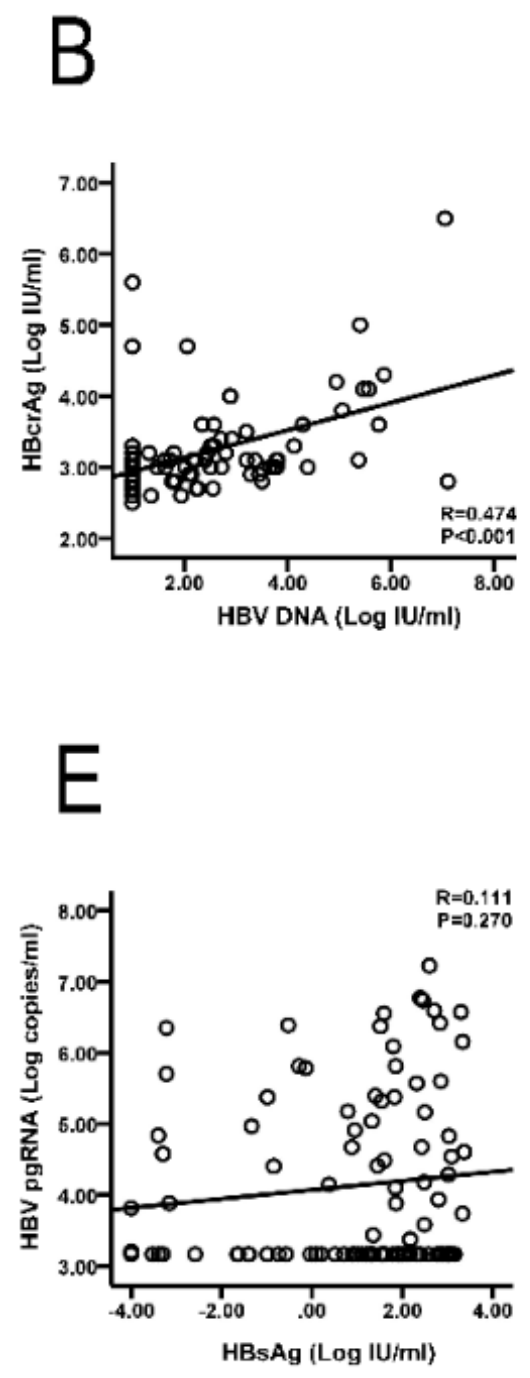

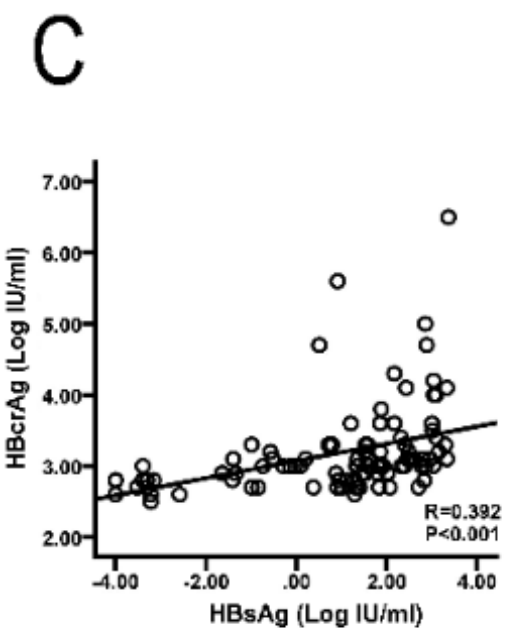

$\mathrm{F}$



Figure 2 
Linear regression analyses for the correlations between HBV biomarkers in patients coinfected with

HBV/HCV. A. HBV DNA was significantly correlated with HBsAg (Fig. $2 A ; R=0.476, R^{2}=0.227, b=0.463$, and $P<0.001$ ) B. HBV DNA was significantly correlated with HBcrAg (Fig. $2 \mathrm{~B} ; \mathrm{R}=0.474, \mathrm{R}^{2}=0.225, \mathrm{~b}=$ 0.474 , and $P<0.001$ ). C. HBsAg also showed a positive correlation with $\mathrm{HBcrAg}$ (Fig. $2 \mathrm{C} ; \mathrm{R}=0.392, \mathrm{R}^{2}=$ $0.153, \mathrm{~b}=0.392$, and $P<0.001)$. D-F. HBV pgRNA had no correlations with HBV DNA, HBsAg, or HBcrAg (Fig. 2D-F; HBV DNA, R = 0.017, $\mathrm{R}^{2}=0.0003, \mathrm{~b}=-0.017$, and $P=0.864 ; \mathrm{HBsAg}, \mathrm{R}=0.111, \mathrm{R}^{2}=0.012, \mathrm{~b}=$ 0.111 , and $P=0.270$; and HBcrAg, $\mathrm{R}=0.086, \mathrm{R}^{2}=0.0037, \mathrm{~b}=-0.086$, and $P=0.395$, respectively).

HBV, hepatitis B virus; HCV, hepatitis C virus; HBsAg, hepatitis B surface antigen; HBcrAg, hepatitis B corerelated antigen; pgRNA, pregenomic RNA
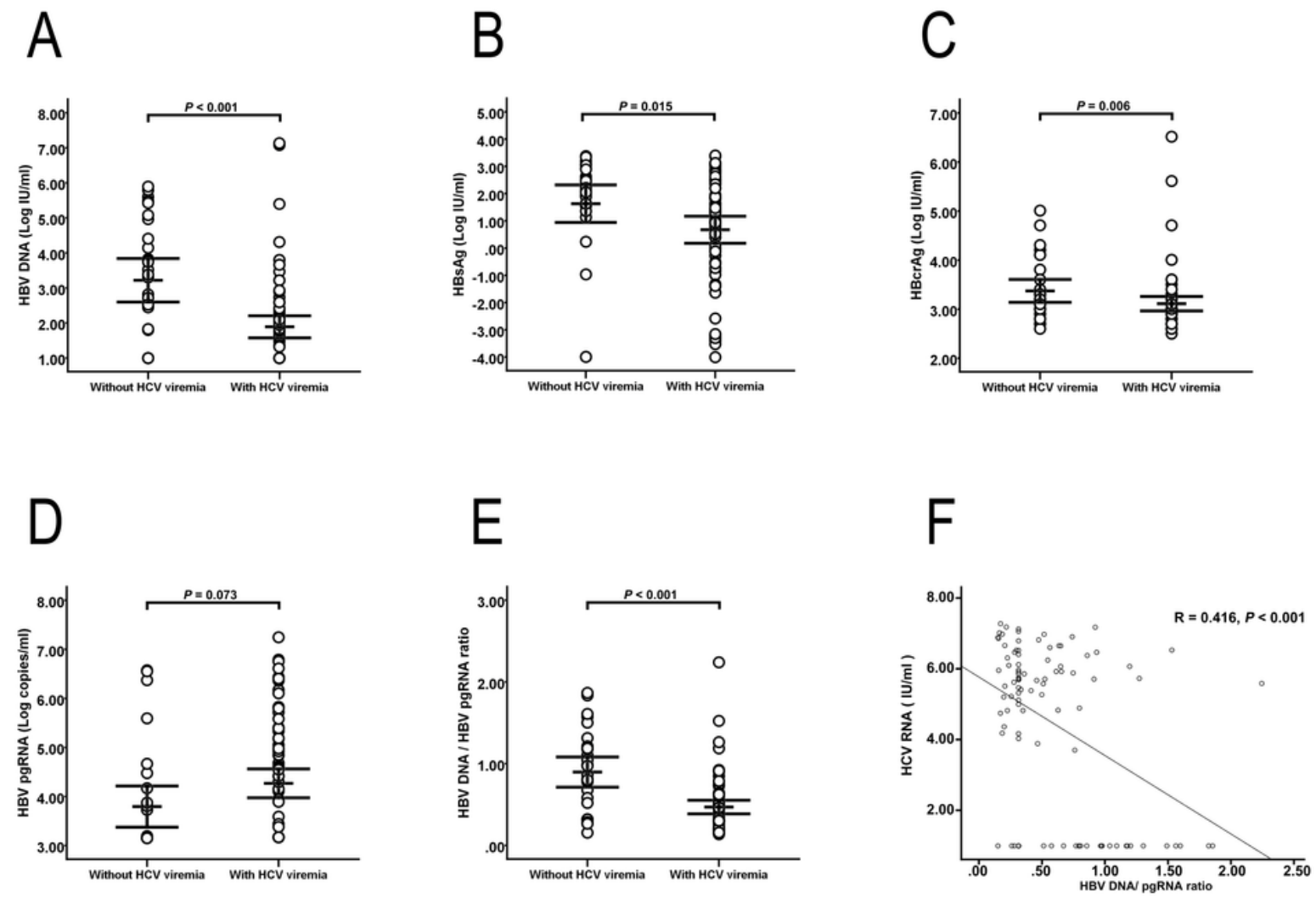

\section{Figure 3}

HBV biomarker expression levels in chronic HBV/HCV coinfected patients with $(n=71)$ and without $(n=$ 29) HCV viremia. A-C. The HBV DNA, HBsAg and HBcrAg levels of patients with HCV viremia were significantly lower than those of patients without viremia (Fig. 3A-C; HBV DNA, $P<0.001 ; \mathrm{HBsAg}, P=$ 0.015 ; and HBcrAg, $P=0.006$, respectively). D. The HBV pgRNA level of patients with viremia trended higher than that of patients without viremia (Fig. 3D; $P=0.073$ ). E. Patients with viremia had a lower HBV 
DNA:HBV pgRNA ratio (Fig. 3E; $P<0.001$ ). F. The amount of HCV RNA had a negative correlation between HCV RNA and HBV DNA/ pgRNA ratio (Fig. 2A; $R=0.416, \mathrm{R}^{2}=0.173, \mathrm{~b}=-0.416$, and $P<0.001$ ).

HBV, hepatitis B virus; HCV, hepatitis C virus; HBsAg, hepatitis B surface antigen; HBcrAg, hepatitis B corerelated antigen; pgRNA, pregenomic RNA

\section{Supplementary Files}

This is a list of supplementary files associated with this preprint. Click to download.

- SupplementaryTable.docx 